\title{
PERSPECTIVE
}

\section{Central retinal vein occlusion: what's the story?}

\author{
Tom H Williamson
}

Central retinal vein occlusion (CRVO) has been a profitable area of study for many investigators. Shameful then that we still do not understand its pathogenesis or know, definitively, how to treat the condition. Many questions still arise when CRVO is considered. Some of these are outlined in this perspective, hopefully as a guide to future investigation.

\section{Terminology}

If confusion over nomenclature is an indicator of confusion over the subject then CRVO is no different. Leibreich in 1854 first described the clinical appearance of CRVO as 'retinal apoplexy' followed closely by Leber in 1877 who preferred 'haemorrhagic retinitis'. ${ }^{2}$ We now use 'central retinal vein occlusion' assuming the presence of a blockage of the vein in the optic nerve head. Hayreh coined the phrases 'venous stasis retinopathy' for the milder types of CRVO and 'haemorrhagic retinopathy' for the more severe disease. $^{3}$ Similarly, the terms 'ischaemic' and 'nonischaemic' CRVO have been employed ${ }^{4}$ and 'indeterminate' used for those cases which did not fit easily into the previous categories. ${ }^{5}$ Gass has described some eyes as 'impending, incipient, partial or incomplete' when patients are asymptomatic or have mild transient visual disturbance. ' 'Impending' and also 'incipient' tend to suggest a risk of the development of CRVO in the future but a progressive situation which is not part of the natural history of the condition needs to be proved. Do these patients develop an acute CRVO at a future date or do they gradually develop cystoid macular oedema and capillary dropout as is expected in other cases of CRVO? Walsh further classified a mixed group of retinal vein occlusions into primary retinal vein occlusion when there is no systemic disease and secondary CRVO in which systemic disease is present. $^{6}$ These varied terminologies can lead to some confusion-for example, the term 'venous stasis retinopathy' may be confused with the stasis retinopathy from carotid artery disease for which the same name has been used, ${ }^{7}$ and 'haemorrhagic retinopathy' leads the clinician to believe that extensive retinal haemorrhages must be present for ischaemia, but this is not always so. Therefore, it may be more appropriate to employ non-ischaemic and ischaemic CRVO perhaps with partial ischaemia used to locate those eyes which cannot be placed into the previous two categories.

\section{Pathogenesis}

IS THROMBUS PRESENT IN THE CENTRAL RETINAL VEIN? Von Michel in 1878 reported the pathological findings of two cases of CRVO one with proliferation of the intima of the vein and one with thrombus formation in the lumen. ${ }^{8}$ Many of his contemporaries believed that stagnation in the central retinal artery caused secondary thrombosis and obstruction of the central retinal vein. ${ }^{9-12}$ Arguing against the presence of thrombosis, Verhoeff reviewed 39 cases in the literature and concluded that only two had pathological evidence of thrombosis. He believed that the blockage was due to a venous channel dissecting through intimal thickening of the wall of the vein, ${ }^{13}$ a finding however which he also found in patients with glaucoma. ${ }^{14}$ Some felt at this time that congenital vascular anomalies caused CRVO ${ }^{1516}$ while collateral venous channels were protective. ${ }^{17}$ Pathological studies performed on cases of rubeotic glaucoma demonstrate thrombus but has this occurred secondarily to the glaucoma ${ }^{18}$ Not until Green et al examined 29 eyes were thrombi found in the venous lumen of a few cases of non-rubeotic eyes. ${ }^{19}$ A small group of four patients was examined within 24 hours of occlusion and found to have thrombus in the vein close to the lamina cribrosa. None were typical cases of CRVO, consisting of an infant of 8 months with Reye's syndrome, a patient with massive intracranial haemorrhage and papilloedema, another with acute myelogenous leukaemia, and the remaining patient with myocardial infarction but no clinical evidence of CRVO. Attempts to find impaired haemostasis and therefore a risk of thrombosis in CRVO have shown that, although differences exist between cohorts of patients, specific abnormalities in individuals are rare (Table 1). ${ }^{20}$ Recently, activated protein C (APC) resistance was found in $12 \%$ of patients with CRVO compared with $5 \%$ of controls taken from the general population. ${ }^{20}{ }^{21}$ This factor is implicated in haemostatic disease ${ }^{22} 23$ and is much commoner than antithrombin III, protein $\mathrm{C}$ and S deficiency. An even higher proportion (26\%) was found in a study of patients of less than 50 years of age but no controls were examined. ${ }^{24}$ The cut off value for the diagnosis of APC resistance in this study was higher $(<2.8)$ than our study $(<2.1)$ which may explain the increased proportion of young patients diagnosed. No difference with age was noted by us but the numbers of patients were small.

DOES STASIS OF VENOUS BLOOD FLOW OCCUR BECAUSE OF INCREASED BLOOD VISCOSITY?

Has the drainage of the retina faltered not because of thrombus formation but because of stasis of blood flow from increased blood viscosity? Blood viscosity is important in venous circulations because the pseudoplastic properties of blood lead to a disproportionate rise in viscosity at low shear rates (for example, slow venous flow). The effects of this can be seen in the hyperviscosity syndromes which manifest retinal features which are indistinguishable from CRVO. ${ }^{25-28}$ Blood viscosity factors are increased in CRVO compared with controls, ${ }^{29}{ }^{30}$-for example, in our studies reduced red cell deformability was the key abnormality ${ }^{20}$ but a variety of abnormalities have been found. ${ }^{29-36}$ In addition the viscosity appears to be temporarily raised at the time of occlusion. ${ }^{20}$ Our blood viscosity variables were correlated with blood flow factors on Doppler ultrasound but the correlations were weak and do not explain all of the reductions in blood velocities (Table 2). Therefore, although viscosity is associated with the condition and may play some role in the pathogenesis other factors must also be present. Of course the measures of systemic viscosity do not directly measure the viscosity 
Table 1 Haemostatic variables which have shown differences between patients with CRVO and controls

\begin{tabular}{|c|c|c|}
\hline & Increased & Decreased \\
\hline \multirow[t]{3}{*}{ Trope $e a^{29}$} & Factor VIII & \multirow{7}{*}{$\begin{array}{l}\text { Antithrombin } 3 \\
\text { Platelets }\end{array}$} \\
\hline & Fibrinopeptide A & \\
\hline & $\beta$ Thromboglobulin & \\
\hline \multirow[t]{2}{*}{ Dodson et al ${ }^{132}$} & $\beta$ Thromboglobulin & \\
\hline & Platelet factor 4 & \\
\hline Walsh et $a l^{6}$ & Platelet coagulant & \\
\hline Gonder et al ${ }^{133}$ & Platelet coagulant & \\
\hline \multirow[t]{5}{*}{ Pandolfi et al ${ }^{134}$} & Platelet adhesiveness & \multirow{5}{*}{$\begin{array}{l}\text { Fibrinolytic activity venous } \\
\text { walls }\end{array}$} \\
\hline & Factor V & \\
\hline & Factor VIII & \\
\hline & Inhibitors of urokinase & \\
\hline & Inhibitors of plasmin & \\
\hline \multirow{3}{*}{ Williamson et $\mathrm{al}^{20}$} & Antithrombin III & \multirow{3}{*}{$\begin{array}{l}\text { Activated protein } \mathrm{C} \\
\text { resistance }\end{array}$} \\
\hline & Von Willebrand factor & \\
\hline & $\begin{array}{l}\text { Plasminogen activator } \\
\text { inhibitor }\end{array}$ & \\
\hline
\end{tabular}

Table 2 Blood viscosity correlations with Doppler velocities in the central retinal vein ( $b$ values from multivariate linear regression analysis, $p<0.05$ )

\begin{tabular}{ll}
\hline Eyes with CRVO & Minimum velocity \\
Red cell aggregation & -0.29 \\
Fellow eyes & Maximum velocity \\
Relative blood viscosity & -0.29 \\
\hline
\end{tabular}

present in the vein which may be higher than that recorded in the laboratory.

WHAT ABOUT THE ARTERIES?

Coats in 1904 noted that angiosclerosis was associated with $\mathrm{CRVO}^{37}$ since when common systemic vascular disorders such as hypertension, arteriosclerosis, and diabetes have been linked to the condition (Table 3). Could thickening of the arterial wall from sclerosis be reducing the calibre of the vein or perhaps disturbing the pulsatile blood flow relation that exist between the central retinal artery and vein? ? $^{38-40}$

Hayreh among others argued that central retinal artery occlusion is an essential component in the pathogenesis of CRVO and once believed that the ischaemic form of CRVO was due to a combination of arterial and venous occlusion. Evidence for the hypothesis was provided by experimental studies on monkeys. Occlusion of the central retinal vein and temporary occlusion of the central retinal artery at their emergence from the optic nerve produced a clinical appearance in the retina with some similarities to CRVO. ${ }^{41}$ Occlusion of the central retinal vein alone at this site did not. ${ }^{41}$ Experimental blockage of the central retinal vein distal to the optic nerve head ignored the influence of collateral venous channels around the nerve. Fujino and colleagues, therefore, injected Neoprene into owl monkeys to occlude the vein at the optic nerve head ${ }^{42}$ producing a haemorrhagic retinopathy with evidence of back pressure on the arterial circulation. In the same set of experiments occlusion of the vein at its emergence from the nerve produced only a temporary and reversible increase in retinal venous congestion.

Reduced arterial perfusion pressure on ophthalmodynamometry and prolonged arteriovenous dye transit times on fluorescein angiography have also been used as indica-

Table 3 Reported prevalences of systemic abnormalities in CRVO

\begin{tabular}{ll}
\hline Hypertension & $38-61 \%^{7074135136}$ \\
Diabetes mellitus & $13-15 \%^{70136}$ \\
Arteriosclerosis & $21 \%^{54}$ \\
Abnormal glucose tolerance test & $17.5-34 \%^{93} 135$ \\
$\begin{array}{l}\text { Hypercholesterolaemia or } \\
\text { hypertriglyceridaemia }\end{array}$ & $32-57 \%^{93135136}$ \\
$\begin{array}{l}\text { Increased plasma gammaglobulin levels } \\
\text { Cryofibrinogenaemia }\end{array}$ & $28 \%{\text { (increased IgA levels in } 17 \%)^{135}}^{135}$ \\
$\begin{array}{l}\text { Increased plasma antiphospholipid } \\
\text { antibodies }\end{array}$ & $12 \%{ }^{135}$ \\
\hline
\end{tabular}

tors of a primary arterial problem. ${ }^{43} 44$ The findings could easily be due to back pressure on the arterial circulation from the congested veins. Doppler studies have indicated reduced blood velocities in the retinal vein and artery, being more pronounced in the vein and particularly marked within 3 months of onset of the occlusion. ${ }^{45}$ These suggest that unlike the acute episodes usually associated with retinal artery occlusion there is a prolonged reduction in retinal blood flow lasting a few months. This is a feature which should allow application of therapeutic methods but which has yet to be fully exploited.

Caroticocavernous sinus fistula which produces increased venous pressure in the orbit may demonstrate the retinal features of CRVO. ${ }^{47-49}$ Secondary central retinal arterial occlusion or 'steal' from the arterial circulation cannot be excluded but most likely the condition provides evidence for an outflow obstruction. Carotid artery stenosis however can produce a venous stasis retinopathy with venous dilatation and retinal haemorrhages but microaneuysms, retinal emboli, and low intraocular pressure are also seen. ${ }^{7}$ Hayreh et al have suggested that systemic arterial hypotension during sleep is implicated in the pathogenesis of CRVO. ${ }^{50}$

McLeod investigated patients with combined occlusion of the cilio-retinal artery and central retinal vein showing that retinal haemorrhages a key feature of CRVO were less prominent in the area of the arterial infarct than in the surrounding retina. ${ }^{5152} \mathrm{He}$ cited this as evidence that arterial occlusion was less likely as a primary mechanism. Indeed video fluorescein angiography of such patients shows pulsations of dye in the arteries suggesting back pressure without occlusion. ${ }^{53}$ These may also be seen in the retinal circulation of cases of CRVO with dye gradually progressing through the arterioles (unpublished data).

DOES CRVO SHARE SIMILAR RISK FACTORS TO ARTERIAL

DISEASE?

The condition is associated with common systemic vascular disorders such as hypertension, arteriosclerosis, and diabetes. However, dissimilarities with arterial disease exist. Ellis et al found that $51 \%$ of patients with vein occlusion smoked compared with $40 \%$ of controls but that all patients with central retinal artery occlusion smoked. ${ }^{54}$ Carotid artery disease is associated with retinal artery occlusion but not with CRVO. ${ }^{55}$ Reduced mean optic disc area, a risk factor for anterior ischaemic optic neuropathy, is not found in eyes with CRVO. ${ }^{56-58}$ An increase in mortality is expected in patients suffering arterial occlusion but this has not been reliably found in CRVO. ${ }^{59-62}$ Furthermore, it is uncertain whether an increase in cardiovascular or cerebral vascular mishaps affects these patients. ${ }^{63}$ In a recent comparison of arteriopathic risk factors including smoking, systemic hypertension, history of myocardial infarction, or cerebrovascular accident and hypercholesterolaemia we were unable to show an increased prevalence compared with a sample of the general population (unpublished data). In contrast, two larger studies using hospital based controls have shown increased risk of CRVO with arteriopathy, plasma glucose level, and systemic blood pressure. ${ }^{6465}$ Reduced risk was associated with regular exercise, alcohol intake, and high density lipoprotein levels.

WHAT ROLE HAS INTRAOCULAR PRESSURE?

A popular theory exists that raised intraocular pressure causes external compression of the central retinal vein as it passes through the lamina cribrosa. This results in turbulent blood flow distal to the constriction and subsequent thrombus formation. An association with CRVO and raised intraocular pressure has been described 
but turbulent flow is not present on Doppler studies. ${ }^{45} 66$ This is not surprising because low blood velocity, reduced vessel calibre, and increased viscosity protect against turbulence (according to Reynold's equation) and are all present in the central retinal vein. ${ }^{67}$

CRVO is detected in $4 \%$ to $4.5 \%$ of eyes with primary open angle glaucoma ${ }^{68}{ }^{69}$ and primary open angle glaucoma or ocular hypertension in $4 \%$ to $43 \%$ of patients with CRVO. $^{70-75}$ Although CRVO causes an initial drop in intraocular pressure which recovers within a few weeks ${ }^{71} 76$ an increase in average intraocular pressures has been found compared with controls. ${ }^{77}$ Large rises in intraocular pressure with changes in posture with CRVO have been measured, ${ }^{78}$ reflecting the presence of open angle glaucoma in the condition. ${ }^{80}$ The role of intraocular pressure in the aetiology of CRVO has been questioned ${ }^{81}$ because a similar incidence of underlying medical conditions has been reported in patients with and without raised intraocular pressure ${ }^{74}$ and recurrent CRVO is as common whether intraocular pressure was raised or not. Even so there does appear to be a connection between raised intraocular pressure and CRVO but the mechanism by which these interact remains obscure.

\section{IS THERE INFLAMMATION?}

An inflammatory aetiology was first suggested by finding young patients with influenza and CRVO.$^{15}$ Cases of tubercle of the vein, paranasal sinusitis, cavernous sinus thrombosis, facial erysipelas, ophthalmic herpes zoster associated with CRVO added weight to this contention. ${ }^{82}{ }^{83}$ Later increased $\mathrm{C}$ reactive protein levels and increased erythrocyte aggregation rates were found. ${ }^{70}{ }^{84}$ Local inflammation has been detected pathologically but usually in rubeotic eyes $^{19}$ and immunological diseases have been associated with CRVO (Table 4) but a definitive inflammatory process has not been determined. Also young patients show no predilection for inflammation in recent studies. $^{85-90}$

ARE BRANCH RETINAL VEIN OCCLUSIONS A SPECTRUM OF THE SAME DISEASE AS CRVO?

Retinal vein occlusions are often grouped together in studies. While this may be appropriate with central and hemiretinal vein occlusions where the sites of blockage are likely to be anatomically very close this does not apply to branch retinal vein occlusion (BRVO) which also has aetiological differences. For example, raised intraocular pressure is more common in CRVO than BRVO (6\% to $13 \%$ with raised intraocular pressure). ${ }^{54} 70$ Likewise, only $1 \%$ of glaucoma patients have evidence of branch vein occlusion. ${ }^{68}$ Hypermetropia, arteriosclerosis, and high blood pressure are commoner in BRVO, whereas raised erythrocyte sedimentation rate is commoner in CRVO. ${ }^{70}$ Separation of the two conditions during studies is prudent.

WHAT TESTS SHOULD BE CARRIED OUT IN THE CLINIC?

The primary roles of investigation of CRVO in the clinical setting have been to identify underlying systemic and ocular conditions which require treatment. Intraocular pressure should be tested and carotid bruits auscultated in case of ocular ischaemic syndrome. For the latter, ophthalmo-

Table 4 Case associations of CRVO with inflammatory or immunological disease

Moyamoya disease $\mathrm{e}^{139}$

Systemic lupus erythematosis ${ }^{140}$

Tuberculosis ${ }^{141}$

Acute multifocal placoid pigment epitheliopathy ${ }^{142}$

Acute multifocal

Optic neuritis

AIDS $^{87143144}$

Table 5 Positive blood results in the author's studies

Full blood count

Erythrocyte sedimentation rate Hypercholesterolaemia

dynamometry of the central retinal artery perfusion pressure may be helpful and colour Doppler imaging of the orbit and carotid arteries performed when suspicion is high. In a cohort of 90 patients with occlusion investigated for various general medical conditions the laboratory tests shown in Table 5 yielded fruitful results. These are worth investigating routinely because the recurrence rate of CRVO may be reduced if general medical conditions are treated..$^{91}{ }^{92}$ Whether the results of these investigations only reflect the elderly age of the patients is a contention but recent studies suggest that systemic blood pressure and glaucoma are increased relative to controls. ${ }^{6465}$ Blood cholesterol levels, although often increased in patients with vein occlusion, ${ }^{93}$ are not higher than age matched controls. ${ }^{64}$ High density lipoprotein levels are significantly lower ${ }^{64}$; therefore, the clinician should offer the patient dietary advice if raised cholesterol levels are found especially considering the association of CRVO with arteriosclerosis.

Testing for multiple myeloma with plasma protein electrophoresis should be restricted to patients in whom there is a high index of suspicion-for example, bilateral CRVO. The therapeutic indications of relative changes in viscosity or coagulation are still poorly defined because abnormalities warranting specific intervention are likely to be rare. Viscosity could be investigated if rheological therapy is being considered and haemostasis perhaps tested in young patients. Treatment of patients with abnormalities-for example, APC resistance, has not yet been assessed.

\section{Neovascularisation and neovascular glaucoma}

Twenty one per cent of cases of CRVO develop iris neovascularisation usually by 6 or 7 months after onset although it can occur as late as 24 months from presentation. ${ }^{94-96}$ Neovascular glaucoma develops in $8 \%$ of $\mathrm{CRVO}^{97}$ overall, $67-82 \%$ of ischaemic CRVO, ${ }^{595}$ and as little as $1 \%$ of those with non-ischaemic disease ${ }^{85}{ }^{95} 97$ Although iris neovascularisation may occur as late as 24 months after onset ${ }^{94}$ the majority of cases, $71 \%$ patients in one study, ${ }^{95}$ occur within the first 6 months. Patients may experience a late reduction in vision followed by development of ischaemia and neovascularisation, probably indicating a reblockage of the vein. Progressive development of ischaemia can also occur, the mechanism of which is unknown. Left untreated, iris neovascularisation causes blindness (no perception of light) in $76 \%$ and results in phthisis bulbi or enucleation for pain in $26 \% .{ }^{98}$

New vessels in the posterior segment usually occur in only $5-7 \%$ of eyes. ${ }^{97}$ In contrast, retinal new vessels in BRVO occur in $23 \% .{ }^{97}$ Whereas new vessels of the iris appear within the first 6 months new vessels of the disc and retina take longer to appear, usually 1 year after the occlusion occurs. ${ }^{99}$ Theoretically, a lack of viable retinal vascular endothelium (demonstrated histologically) prevents neovascularisation whereas the iris vasculature can still respond. $^{100}$

HOW CAN WE PREDICT THOSE PATIENTS WITH A RISK OF IRIS NEOVASCULARISATION?

For classification visual acuity, ophthalmoscopy, relative afferent pupillary defect, visual field assessment, and investigations such as electroretinography, fluorescein angiography and colour Doppler imaging have been used. An 
Table 6 A suggested management protocol for patients with CRVO

\begin{tabular}{|c|c|}
\hline \multicolumn{2}{|c|}{ Less than 3 months from onset: } \\
\hline \multirow{2}{*}{\multicolumn{2}{|c|}{$\begin{array}{l}\text { If neovascularisation treat with panretinal photocoagulation } \\
\text { If no neovascularisation and: }\end{array}$}} \\
\hline & \\
\hline RAPD & $\begin{array}{l}20 \text { degrees or more (cross polarised filters, if } \\
\text { other eye normal) }\end{array}$ \\
\hline Visual acuity & $\begin{array}{l}\text { Less than } 6 / 60 \text { (if no cystoid macular } \\
\text { oedema) }\end{array}$ \\
\hline Doppler ultrasound & $\begin{array}{l}\text { Vmin less than } 3 \mathrm{~cm} / \mathrm{s} \text { (repeated } \\
\text { examinations) }\end{array}$ \\
\hline \multicolumn{2}{|c|}{$\begin{array}{l}\text { Manage with frequent observation (every } 2 \text { weeks) or prophylactic } \\
\text { panretinal photocoagulation and monthly observation }\end{array}$} \\
\hline \multicolumn{2}{|c|}{$\begin{array}{l}\text { After } 3 \text { months from onset: } \\
\text { If neovascularisation treat with panretinal photocoagulation } \\
\text { If no neovascularisation and: }\end{array}$} \\
\hline ERG & Reduced flash photopic wave amplitude \\
\hline RAPD & $\begin{array}{l}20 \text { degrees or more (cross polarised filters, if } \\
\text { other eye normal) }\end{array}$ \\
\hline Visual acuity & $\begin{array}{l}\text { Less than } 6 / 60 \text { (if no cystoid macular } \\
\text { oedema) }\end{array}$ \\
\hline $\begin{array}{l}\text { Fluorescein angiography } \\
\text { Manage with frequent obse } \\
\text { monthly) or panretinal pho }\end{array}$ & $\begin{array}{l}\text { Capillary dropout } 10 \text { disc diameters or more } \\
\text { ation (monthly up to } 6 \text { months then } 2 \\
\text { coagulation }\end{array}$ \\
\hline
\end{tabular}

appropriate protocol for this purpose from our own studies is provided in Table 6 .

Visual acuity shows some predictive power for the development of neovascular glaucoma ${ }^{66}$ but its value is lessened because cystoid macular oedema is a common complication of CRVO reducing visual acuity in many non-ischaemic vein occlusions. A quantitative assessment of relative afferent pupillary defect (RAPD) can be performed using neutral density filters ${ }^{101} 102$ or cross polarising filters. ${ }^{103}$ The test is dependent upon the presence of a healthy fellow eye which may preclude the investigation of a significant proportion of patients. Ophthalmoscopic variables such as retinal haemorrhages or cotton wool spots are unreliable. $^{45}$

\section{FLUORESCEIN ANGIOGRAPHY}

Paton in 1964 first described the fluorescein angiographic appearance of CRVO. ${ }^{104}$ Retinal capillary non-perfusion is seen in $22 \%{ }^{105}$ and $36 \%{ }^{85}$ and has been shown repeatedly to predict the development of rubeosis. ${ }^{98} 106-108$ Unfortunately, the identification and quantification of this sign is subjective and difficult to standardise. Serial fluorescein angiograms have shown that capillary closure increases with time, up to 3 months, so that early examination may underestimate the final extent of the retinal ischaemia. ${ }^{9698109}$ The progressive loss of capillaries with time has also been demonstrated histologically in experiments using monkeys. ${ }^{41}$ Some of the high so called 'conversion' rates (9-20\%) from non-ischaemic to ischaemic CRVO can be explained by the slow loss of capillaries and gradual increase in non-perfusion. ${ }^{3} 859495$

$\mathrm{Up}$ to one third of fluorescein angiograms in CRVO are inadequately assessed because of the presence of such factors as retinal haemorrhages and medial opacities ${ }^{110}$ and in $11 \%$ assessment of the perifoveal arcade cannot be performed. ${ }^{96}$ In addition, because of the largely subjective nature of fluorescein angiography, agreement between two assessments by the same observer may be as low as $68 \% .^{111}$ Using forced choice methodology only $35 \%$ of examiners make what is considered to be a correct classification of ischaemia.

An intact perifoveal arcade provides a good indicator for recovery of visual acuity, cystoid macular oedema occurring if there are breaks in the continuity or if severe venous leakage is present. ${ }^{96} 106$ Transit of fluorescein dye from the arterial to the venous retinal circulations can be used to indicate a risk of ischaemia ${ }^{95}$ especially in patients examined less than 3 months after onset. ${ }^{106}$
Table 7 The measurements from ERG which were most predictive of iris neovascularisation in various studies

\begin{tabular}{ll}
\hline Scotopic measurements: & \\
Sabates et al & b/a ratio \\
Kaye et al ${ }^{116}$ & b wave implicit time \\
Hayreh et al ${ }^{114}$ & b wave amplitude \\
Johnson et al ${ }^{115}$ & log K \\
Breton et al & multiple combined measures \\
Photopic measurements: & \\
Morrell et al l117 $^{113}$ & flicker implicit times \\
Williamson et al & b/a ratio \\
\hline
\end{tabular}

ELECTRORETINOGRAPHY (ERG)

Henkes in 1953 provided the first large series on electroretinography in CRVO. ${ }^{112}$ Since then a number of investigators have found that ERG is a useful test for detecting ischaemia (Table 7). ${ }^{68110}{ }^{113-117}$ The predictive potential may be superior to fluorescein angiography but the most efficient testing strategy to employ or part of the ERG waveform to measure is uncertain.

A common abnormality is a reduction in the $b$ wave or b/a ratio but many other measurements are available such as $a$ and $b$ wave implicit times or variables from the physiological compression formula of Naka and Rushton. The ERG may be used to measure photopic or scotopic responses, colour response, or flicker response. Recently, shortened protocols have been identified from receiver operator coefficient curves-for example, a light adapted flash response, and $b$ wave amplitude can be used effectively in the busy clinical environment. ${ }^{118}$

COLOUR DOPPLER IMAGING

This new technique has recently been used to predict the onset of iris neovascularisation in CRVO from low venous velocities. ${ }^{40456}$ It can be used to examine patients within 3 months of onset of the occlusion when fluorescein angiographic assessment is difficult (because capillary occlusion may not have developed and retinal haemorrhages are present). The non-invasive nature of the test allows repeated examinations. The machinery although expensive is usually available in radiology departments where colour Doppler imaging is used routinely to examine other organs. However, the inconvenience of referring patients to radiology means there is a need for Doppler facilities on ocular ultrasound devices in eye clinics if the method is to be used regularly.

WHAT IS THE VISUAL PROGNOSIS?

Non-ischaemic CRVO has good recovery of visual acuity ${ }^{3}$ whereas ischaemic cases have a poor prognosis for the recovery of vision, ${ }^{85}{ }^{95} 107$ - for example, a prospective study found that the final visual acuity was $3 / 60$ or worse in $87 \%$ of the ischaemic group whereas the non-ischaemic group had $6 / 18$ vision or better in $80 \%,{ }^{95}$ and in a retrospective study $93 \%$ of ischaemic CRVO culminated in a final visual acuity of less than $6 / 60$ in contrast with $50 \%$ of non-ischaemic eyes. ${ }^{85}$ In our own studies the presenting visual acuity was the best predictor of final visual acuity because most patients did not change (57\%). Almost equal proportions deteriorated and improved their visual acuities (23\% and $20 \%$ respectively). The frequency of bilaterally severely reduced vision was $11 \%$ because these patients often had CRVO bilaterally or other ocular pathology affecting their fellow eyes.

\section{Treatment of CRVO}

The prolonged partial occlusion of the retinal vein (as opposed to the rapid and short occlusion seen with artery occlusion) and the slowly progressive development of ischaemia or macular oedema should make planned treatment of the condition possible. Despite this, the mainstay 
of treatment of CRVO is by panretinal photocoagulation to prevent or treat neovascularisation. Laatikainen et al, in a prospective randomised trial, determined that prophylactic xenon panretinal photocoagulation reduced the incidence of neovascularisation and cystoid macular oedema but had no effect on visual acuity. ${ }^{119}$ These findings have been confirmed $^{120}$ and others have used panretinal photocoagulation to reverse neovascular glaucoma and rubeosis. $^{9899108121}$ More recently, however, the CRVO study group recommended providing frequent follow up of at risk patients and application of laser when neovascularisation occurs ${ }^{122}$ because there was no benefit of prophylactic therapy over therapy when complications arise. The follow up recommended was at least monthly and perhaps more in the early stages of the condition. Also, larger numbers of personnel were employed in follow up (ophthalmologists, photographic reading centres, and optometrists) than would be employed in the usual clinical environment. Twenty per cent of the early treatment group developed iris neovascularisation so that even these patients require follow up but fewer of this group ultimately had uncontrolled neovascular glaucoma despite worse entry level criteria. Hayreh et al found no benefit from laser photocoagulation in CRVO, stating that photocoagulation has a detrimental effect on visual field. Unfortunately, the process used for patient selection in their study was flawed which may have affected the results. ${ }^{123}$

Anticoagulants and fibrinolytic agents have been tried unsuccessfully to treat the condition. ${ }^{124-126}$ Although streptokinase was successful in improving visual recovery it was thought inappropriate because of a risk of vitreous haemorrhage. With improved vitrectomy techniques now available this agent might warrant reapproval. Anticoagulation might also be targeted to patients with specific thrombogenic abnormalities such as APC resistance.

An exciting but unpredictable therapy is inducement of chorioretinal anastomosis by high energy argon laser to retinal venules. ${ }^{127-129}$ If successful this can rapidly resolve macular oedema and improve vision in non-ischaemic CRVO (33.3\% of patients). Personal communications from other centres have indicated some risk of neovascularisation, retinal tear formation, and detachment.

Haemodilution to reduce the viscosity of the blood and thereby increase the perfusion of the retina has been effective in randomised controlled trials, improving the visual outcome in non-ischaemic CRVO. ${ }^{130}$ This requires intensive venesection and considerable reduction of the haematocrit by replacement of whole blood by plasma expanders a process which may only be appropriate in younger patients or under general medical supervision. Administration of troxerutin also reportedly improves visual recovery. ${ }^{131}$

There is still need for a definitive therapy perhaps targeted at the period within 3 months of onset when haemodynamic abnormalities are greatest and before cystoid macular oedema and capillary closure have developed. Also different approaches may be necessary for different subgroups of the condition - for example, those with APC resistance. In the later stages when ischaemia has been allowed to develop panretinal photocoagulation is likely to remain the mainstay of management.

\section{Conclusions}

It has been difficult to prove anything conclusively in the pathogenesis of CRVO but there is evidence for a role for viscosity, raised intraocular pressure, arteriosclerosis, and perhaps thrombosis of the vein. Although the chronic nature of the 'occlusive' process makes the condition amenable to therapeutic intervention, further innovation, or reassessment of existing strategies is required. In the meantime, the clinician should perform some routine clinical and laboratory investigations because of the associations with systemic medical problems. As yet no test alone can predict all those patients who will develop iris neovascularisation; therefore, multiple tests and in some cases repeated tests are appropriate. Once present neovascularisation should be treated by panretinal photocoagulation. CRVO causes severe impairment of vision in a significant proportion of patients because of the frequency of bilateral ocular disease.

TOM H WILLIAMSON

Department of Ophthalmology, St Thomas's Hospital,

Lambeth Palace Road, London SE

1 Liebreich R. Apoplexia retinae. Albrecht von Graefes Arch Ophthalmol $1855 ; 1: 346-51$.

Leber T. Graefe-Seamisch Handbuch der Gestamtem Augenheilkunde. Leibzig: Englelmann, 1877:551.

3 Hayreh SS. So-called 'central retinal vein occlusion'. II. Venous stasis retinopathy. Ophthalmologica 1976;172:14-37.

4 Gass JDM. Stereoscopic atlas of macular diseases: diagnosis and treatment. 4th ed. St Louis: CV Mosby, 1997:546-55.

5 Magargal LE, Brown GC, Augsburger JJ, Parrish RK. Neovascular glaucoma following central retinal vein obstruction. Ophthalmology 1981;88:1095-101.

6 Walsh PN, Goldberg RE, Tox RL, Magargal LE. Platelet coagulant activities in retinal vein thrombosis. Thromb Haemost 1977;38:399-406.

7 Kearns TP, Hollenhorst RW. Venous-stasis retinopathy of occlusive disease of the carotid artery. Proc Mayo Clinics 1973;38:304-12.

8 Michel J. de spontane Thrombose der Vena centralis des opticus. Graefes Arch Ophthalmol 1878;24:37-70.

9 Harms C. Anatomische Untersuchungen uber Gefasserkrankungen im Gebiete der Arteria und Vencentralis retinae und ihre Folgen fur die Cirkulation mit besonderer Berlichsichtigung des sog. hamorrhagischenInfarktes der Netzhaut. Graefes Arch Ophthalmol 1905;61:245.

10 Leber T. Handbuch der gesamten Augenheilkunden. 2nd ed. Leipzig: Engelmann W. 1915:355.

11 Klien BA. Obstruction of the central retinal vein: a clinicopathological analysis. Am f Ophthalmol 1944;27:1339-54.

12 Coats G. Discussion on retinal vascular disease:pathological aspect. Trans Ophthalmol Soc UK 1913;33:30-49.

13 Verhoeff FH. Obstruction of the central retinal vein. Ophthalmic Rev 1906; 25:353.

14 Verhoeff FH. The effect of chronic glaucoma on central retinal vessels. Arch Ophthalmol 1913;42:145-52.

15 Moore RF. Retinal venous thrombosis: a clinical study of 62 cases followed over many years. Br f Ophthalmol 1924;2(suppl):4-90.

16 Gradle HS. The X-ray therapy of retinal vein thrombosis. Am f Ophthalmol 1937;20:1125-31.

17 Verhoeff FH. Obstruction of the central retinal vein. Ophthalmic Rev 1907; 25:353-7.

18 Klien BA. Occlusion of the central retinal vein: clinical importance of certain histopathological observations. Am F Ophthalmol 1953;36:316-24.

19 Green WR, Chan CC, Hutchins GM, Terry JM. Central retinal vein occlusion: a prospective histopathologic study of 29 eyes in 28 cases. Trans Am Ophthalmol Soc 1981;79:371-422.

20 Williamson TH, Rumley A, Lowe GDO. Blood viscosity, coagulation, and activated protein $C$ resistance in central retinal vein occlusion:a population controlled study. Br f Opthalmol 1996;80:203-8.

21 Dhote R, Buohmeyer C, Horrellou MM, Toulan P, Christoforov B. Central retinal vein thrombosis associated with resistance to activated protein $\mathrm{C}$. Am 7 Ophthalmol 1995;120:388.

22 Bertina RM, Koeleman BP, Koster T, Rosendaal FR, Dirven RJ, de Ronde $\mathrm{H}$, et al. Mutation in blood coagulation factor $\mathrm{V}$ associated with resistance to activated protein C. Nature 1994;369:64-7.

23 Aillaud MF, Succo E, Alessi MC, Gandois JM, Gallian P, Morange P. Reistance to activated protein C, diagnostic strategy in a laboratory of haemostasis. Thromb Haemost 1995;74:1197-207.

24 Larson J, Olafsdotter F, Bear D. Activated protein C resistance in young adults with central retinal vein occlusion. Br f Ophthalmol 1996;80:200-2.

25 Rosen ES, Simmons AV, Warnes TW. Retinopathy of Waldenstrom's macroglobulinemia: photographic assessment. Am f Ophthalmol 1968;65: 696-706.

26 Mehta AB, Goldman JM, Kohner E. Hyperleucocytic retinopathy in chronic granulocytic leukaemia:the role of intensive leucapheresis. Br $\mathcal{F}$ Haematol 1984;56:661-7.

27 Thomas EL, Olk RJ, Markman M, Braine H, Patz A. Irreversible visual loss in Waldenstrom's macroglobulinaemia. Br f Ophthalmol 1983;67:102-6.

28 Avashia JH, Fath DF. Bilateral central retinal vein occlusion in Waldenstrom's macroglobulinemia. F Am Optom Ass 1989;60:657-8.

29 Trope GE, Lowe GD, McArdle BM, Douglas JT, Forbes CD, Prentice CM. Abnormal blood viscosity and haemostasis in long-standing retinal vein occlusion. Br f Ophthalmol 1983;67:137-42.

30 Peduzzi M, Debbia A, Guerrieri F, Bolzani R. Abnormal blood rheology in retinal vein occlusion. A preliminary report. Graefes Arch Clin Exp Ophthalmol 1986;224:83-5.

31 Glacet-Bernard A, Chabanel A, Lelong F, Samama MM, Coscas G. Elevated erythrocyte aggregation in patients with central retinal vein occlusion and without conventional risk factors. Ophthalmology 1994;101:14837 .

32 Wiek J, Schade M, Wiederholt M, Arntz HR, Hansen LL. Haemorheological changes in patients with retinal vein occlusion after isovolaemic haemodilution. Brf Ophthalmol 1990;74:665-9.

33 Chabanel A, Glacet Bernard A, Lelong F, Taccoen A, Coscas G, Samama $\mathrm{MM}$. Increased red blood cell aggregation in retinal vein occlusion. $\mathrm{Br} \mathcal{F}$ Haematol 1990;75:127-31. 
34 Wiek J, Schade M, Wiederholt M, Arntz HR, Hansen LL. Haemorheological changes in patients with retinal vein occlusion after isovolaemic .

35 Peduzzi M, Codeluppi L, Poggi M, Baraldi P. Abnormal blood viscosity and erythrocyte deformability in retinal vein occlusion. Am f Ophthalmol 1983; 96:399-400.

36 Ring CP, Pearson TC, Sanders MD, Wetherley Mein G. Viscosity and retinal vein thrombosis. Br f Ophthalmol 1976;60:397-410

37 Coats G. Thrombosis of the central vein of the retina. Roy London Ophthal Hosp Rep 1904;16:62-122.

38 Williamson TH, Barr D, Baxter GM. An understanding of the retinal circulation provided by an anomalous retinal vein. $\mathrm{Br} \quad \mathcal{f}$ Ophthalmol 1994;78:798-9.

39 Williamson TH, Baxter GM, Lowe GDO. The influence of age, systemic blood pressure, smoking and blood viscosity on orbital blood velocities. $\mathrm{Br}$ f Ophthalmol 1995;79:17-22.

40 Williamson TH, Harris A. Color Doppler ultrasound imaging of the eye and orbit: major review. Surv Ophthalmol 1996;40:255-67.

41 Hayreh SS, van Heuven WA, Hayreh MS. Experimental retinal vascular occlusion. I Pathogenesis of central retinal vein occlusion. Arch Ophthalmo 1978;96:311-23.

42 Fujino T, Curtin VT, Norton EWD. Experimental central retinal vein occlusion. A comparison of intraocular and extraocular occlusion. Arch Ophthalmol 1969;81:395-406.

43 Jorizzo PA, Klein ML, Shults WT, Linn ML. Visual recovery in combined central retinal artery and central retinal vein occlusion. Am f Ophthalmol 1987;104:358-63

44 Smith VH. Arterial insufficiency in retinal venous occlusion (a short symposium). Trans Ophthalmol Soc UK 1964;84:581-6.

45 Williamson TH, Baxter GM. Central retinal vein occlusion, an investigation by color Doppler imaging: blood velocity characteristics and prediction of iris neovascularisation. Ophthalmology 1994;101:1362-72.

46 Matsui Y, Katsumi O, Mehta MC, Hirose T. Correlation of electroretinographic and fluorescein angiographic findings in unilateral central retinal
vein obstruction. Graefes Arch Clin Exp Ophthalmol 1994;232:449-57.

47 Brunette I, Boghen D. Central retinal vein occlusion complicating spontaneous carotid-cavernous fistula. Case report. Arch Ophthalmol 1987; 105:464-500

48 Suzuki Y, Kase M, Yokoi M, Arikado T, Miyasaka K. Development of central retinal vein occlusion in dural carotid-cavernous fistula. Ophthalmologica 1989;199:28-33.

49 Pollock S, Miller NR. Central retinal vein occlusion complicating spontaneous carotid-cavernous fistula. Arch Ophthalmol 1986;104:331.

50 Hayreh SS, Zimmerman MB, Podhajsky P, Alward WL. Nocturnal arterial hypotension and its role in optic nerve head and ocular ischemic disorders. Am $\mathcal{F}$ Ophthalmol 1994;117:603-24.

51 McLeod D, Ring CP. Cilio-retinal infarction after retinal vein occlusion. $\mathrm{Br}$ f Ophthalmol 1976;60:419-27.

52 McLeod D. Cilio-retinal arterial circulation in central retinal vein occlusion. Br f Ophthalmol 1975;59:486-92.

53 Schatz H, Fong AC, McDonald HR, Johnson RN, Joffe L, Wilkinson CP, et al. Cilioretinal artery occlusion in young adults with central retinal vein al. Cilioretinal artery occlusion in young a
occlusion. Ophthalmology 1991;98:594-601.

54 Ellis CJ, Hamer DM, Hunt RW, et al. Medical investigation of retinal vein occlusion. BM7 1964;2:1093-8.

55 Peternel P, Keber D, Videcnik V. Carotid arteries in central retinal vessel occlusion as assessed by Doppler ultrasound. Br f Ophthalmol 1989;73: $880-3$.

56 Gusek GC, Jonas JB, Naumann GO. [Retinal vascular occlusions are independent of optic disk size. A morphometric study of 140 patients]. Klin Monatsbl Augenheilkd 1990;197:14-7.

57 Mansour AM, Walsh JB, Henkind P. Optic disc size in central retinal vein occlusion. Ophthalmology 1990;97:165-6.

58 Strahlman ER, Quinlan PM, Enger C, Elman MJ. The cup-to-disc ratio and central retinal vein occlusion. Arch Ophthalmol 1989;107:524-5.

59 Elman MJ, Bhatt AK, Quinlan PM, Enger C. The risk for systemic vascular diseases and mortality in patients with central retinal vein occlusion. $O p h$ thalmology 1990;97:1543-8.

60 Duker JS, Sergott RC, Savino PJ, Bosley TM. Optic neuritis with secondary retinal venous stasis. Ophthalmology 1989;96:475-80.

61 Eckardt C, Gotze O, Utermann D. [Life expectancy of patients with circulatory disorders of the posterior eyeball segment]. Ophthalmologica 1983;187: 34-42.

62 Mansour AM, Walsh JB, Henkind P. Mortality and morbidity in patients with central retinal vein occlusion. Ophthalmologica 1992;204:199-203.

63 Priluck IA, Robertson DM, Hollenhorst RW. Long-term follow-up of occlusion of the central retinal vein in young adults. Am F Ophthalmol 1980;90: 190-202.

64 The Eye Disease Case-Control Study Group. Risk factors for central retinal vein occlusion. Arch Ophthalmol 1996;114:545-54.

65 Glacet-Bernard A, Coscas G, Chabanel A, Zourdani A, Lelong F, Samama MM. Prognostic factors for retinal vein occlusion:prospective study of 175 cases. Ophthalmology 1996;103:551-60.

66 Baxter GM, Williamson TH. Color Doppler flow imaging in central retinal vein occlusion: a new diagnostic technique? Radiology 1993;187:847-50.

67 Williamson TH, Harris JA. Ocular blood flow measurement. Br f Ophthalmol 1994;78:939-45.

68 Dobree JH. Venous obstruction and neovascularisation at the disc in chronic glaucoma. Trans Ophthalmol Soc UK 1957;77:229-37.

69 Hitchings RA, Spaeth GL. Chronic central retinal vein occlusion in glaucoma. Brf Ophthalmol 1976;60:694-9.

70 Appiah AP, Trempe CL. Differences in contributory factors among hemicentral, central, and branch retinal vein occlusions. Ophthalmology 1989;96:364-6.

71 Vannas S, Tarkkanen A. Retinal vein occlusion and glaucoma tonographic study of the incidence of glaucoma and its prognostic significance. $\mathrm{Br} \mathcal{F}$ Ophthalmol 1960;44:583-9.

72 Soni KG, Woodhouse DF. Retinal vascular occlusion as a presenting feature of glaucoma simplex. Br F Ophthalmol 1971;55:192-5.

73 Rath EZ, Frank RN, Shin DH, Kim C. Risk factors for retinal vein occlusions. Ophthalmology 1992;99:509-14.

74 Cole MD, Dodson PM, Hendeles S. Medical conditions underlying retinal vein occlusion in patients with glaucoma or ocular hypertension [see comments]. Br f Ophthalmol 1989;73:693-8.
75 Dryden RM. Central retinal vein occlusion and chronic simple glaucoma. Arch Ophthalmol 1965;73:659-63.

76 Hayreh SS, March W, Phelps CD. Ocular hypotony following retinal vein occlusion. Arch Ophthalmol 1978;96:827-33.

77 Frucht J, Shapiro A, Merin S. Intraocular pressure in retinal vein occlusion. Brf Ophthalmol 1984;68:26-8.

78 Mansons AM, Clearkin L, Bryce I. Mechanisms leading to an acute rise in intraocular pressure in retinal vein oclusion. Eye 1990;4:439-44.

79 Williams BI, Peart WS. Effect of posture on the intraocular pressure of patients with retinal vein obstruction. Br f Ophthalmol 1978;62:688-93.

80 Trew DR, Smith SE. postural studies in pulsatile ocular blood flow. I Ocular hypertension and normotension. Br F Ophthalmol 1991;75:66-70.

81 Smith R. Retinal vein occlusion and glaucoma. (Editorial) $\mathrm{Br} \mathcal{F}$ Ophthalmol 1989;73:691.

82 Verhoeff FH, Simpson GV. Tubercle within central retinal vein: haemorrhagic glaucoma: periphlebitis in other eye. Arch Ophthalmol 1940;24:64555

83 Braendstrup P. Central retinal vein thrombosis and haemorrhagic glaucoma. Acta Ophthalmol(Copenh) Suppl 1950;35:1-159.

84 Dodson PM, Shine B. Retinal vein occlusion: $\mathrm{C}$ reactive protein and arterial hypertension. Acta Ophthalmol (Copenh) 1984;62:123-30.

85 Quinlan PM, Elman MJ, Bhatt AK, Mardesich P, Enger C. The natural course of central retinal vein occlusion [see comments]. Am f Ophthalmol 1990;110:118-23.

86 Dodson PM, Kritzinger EE. Underlying medical conditions in young patients and ethnic differences in retinal vein occlusion. Trans Ophthalmol $1985 ; 104: 114-119$

87 Fong ACO, Schatz H, McDonald HR, Burton TC, Maberley AL, Joffe L, et al. Central retinal vein occlusion in young adults (papillophlebitis). Retina 1991;11:3-11.

88 Walters RF, Spalton DJ. Central retinal vein occlusion in people aged 40 years or less:a review of 17 patients. Br f Ophthalmol 1990;74:30-5.

89 Fong ACO, Schatz H. Central retinal vein occlusion in young adults. Surv Ophthalmol 1993;37:393-417.

90 Frucht J, Yanko L, Merin S. Central retinal vein occlusions in young adults. Acta Ophthalmol (Copenh) 1984;62:780-6.

91 Dodson PM, Kubicki AJ, Taylor KJ, Kritzinger EE. Medical conditions underlying recurrence of retinal vein occlusion. $\mathrm{Br} \mathcal{F}$ Ophthalmol 1985;69:493-6.

92 Dodson PM, Kritzinger EE. Management of retinal vein occlusion. BMF (Clin Res Ed) 1987;295:1434-5.

93 Dodson PM, Galton DJ, Hamilton AM, Blach RK. Retinal vein occlusion and the prevalence of lipoprotein abnormalities. Br f Ophthalmol 1982;66: 161-4.

94 Minturn J, Brown GC. Progression of nonischemic central retinal vein obstruction to the ischemic variant. Ophthalmology 1986;93:1158-62.

95 Zegarra H, Gutman FA, Conforto J. The natural course of central retinal vein occlusion. Ophthalmology 1979;86:1931-42.

96 Sinclair SH, Gragoudas ES. Prognosis for rubeosis iridis following central retinal vein occlusion. Br f Ophthalmol 1979;63:735-43.

97 Hayreh SS, Rojas P, Podhajsky P, Montague P, Woolson RF. Ocular neovascularization with retinal vascular occlusion-III. Incidence of ocular neovascularization with retinal vascular occlusion-Ih. Incidence of ocular neovas-

98 Magargal LE, Donoso LA, Sanborn GE. Retinal ischemia and risk of neovascularization following central retinal vein obstruction. Ophthalmology 1982;89:1241-5.

99 Murdoch IE, Rosen PH, Shilling JS. Neovascular response in ischaemic central retinal vein occlusion after panretinal photocoagulation. $\mathrm{Br} \mathcal{F} O p h$ thalmol 1991;75:459-61.

100 Chan CC, Little HL. Infrequency of retinal neovascularization following central retinal vein occlusion. Ophthalmology 1979;86:256-63.

101 Thompson HS, Corbett JJ, Cox TA. How to measure the relative afferent pupillary defect. Surv Ophthalmol 1981;26:39-42.

102 Servais GE, Thompson HS, Hayreh SS. Relative afferent pupillary defect in central retinal vein occlusion. Ophthalmology 1986;93:301-3.

103 Ramsay A, Williamson TH, Parks S, Keating D. Crossed polarising filters to measure relative afferent pupillary defects:reproducibility, correlation with neutral density filters and use in central retinal vein occlusion. Eye 1995;9:624-8.

104 Paton. Arterial insufficiency in retinal vein occlusion. Trans Ophthalmol Soc UK 1964;84:559-81.

105 Hayreh SS. Classification of central retinal vein occlusion. Ophthalmology 1983;90:458-74

106 Laatikainen L, Kohner EM. Fluorescein angiography and its prognostic significance in central retinal vein occlusion. Brf Ophthalmol 1976;60:4118.

107 Laatikainen L, Blach RK. Behaviour of the iris vasculature in central retinal vein occlusion:a fluorescein angiographic study of the vascular response of the retina and the iris. Br f Ophthalmol 1977;61:272-7.

108 Magargal LE, Brown GC, Augsburger JJ, Donoso LA. Efficacy of panretinal photocoagulation in preventing neovascular glaucoma following ischemic central retinal vein obstruction. Ophthalmology 1982;89:780-4.

109 Laatikainen L. Vascular changes after central retinal vein occlusion. Trans Ophthalmol Soc UK 1976;96:190-2.

110 Hayreh SS, Klugman MR, Beri M, Kimura AE, Podhajsky P. Differentiation of ischemic from non-ischemic central retinal vein occlusion during
the early acute phase. Graefes Arch Clin Exp Ophthalmol 1990;228:201-17.

111 Welch JC, Augsburger JJ. Assessment of angiographic retinal capillary nonperfusion in central retinal vein occlusion. Am f Ophthalmol 1987;103:761-

112 Henkes HE. Electroretinography in circulatory disturbances of the retina. 1 Electroretinogram in cases of occlusion of central retinal vein or one of its branches. Arch Ophthalmol 1953;49:190-201.

113 Breton ME, Quinn GE, Keene SS, Dahmen JC, Brucker AJ. Electroretinogram parameters at presentation as predictors of rubeosis in central retinal vein occlusion patients. Ophthalmology 1989;96:1343-52.

114 Hayreh SS, Klugman MR, Podhajsky P, Kolder HE. Electroretinography in central retinal vein occlusion. Correlation of electroretinographic changes with pupillary abnormalities. Graefes Arch Clin Exp Ophthalmol 1989;227:549-61.

115 Johnson MA, Marcus S, Elman MJ, McPhee TJ. Neovascularization in central retinal vein occlusion:electroretinographic findings. Arch Ophthalmol 1988;106:348-52. 
116 Kaye SB, Harding SP. Early electroretinography in unilateral central retinal vein occlusion as a predictor of rubeosis iridis. Arch Ophthalmol 1988;106: vein occlu.

117 Morrell AJ, Thompson DA, Gibson JM, Kritzinger EE, Drasdo N. Electroretinography as a prognostic indicator of neovascularisation in CRVO. Eye 1991;5:362-8.

118 Williamson TH, Keating D, Bradnam M. Electroretinography of central retinal vein occlusion under scotopic and photopic conditions: what to measure? Acta Ophthalmol Scand 1997;75:86-96.

119 Laatikainen L, Kohner EM, Khoury D, Blach RK. Panretinal photocoagulation in central retinal vein occlusion: a randomised controlled clinical study. Br f Ophthalmol 1977;61:741-53.

120 Laatikainen L. Photocoagulation in retinal venous occlusion. Acta Ophthalmol (Copenh) 1977;55:478-88.

121 May DR, Klein ML, Peyman GA. A prospective study of xenon arc photocoagulation for central retinal vein occlusion. Brf Ophthalmol 1976;60: $816-8$.

122 The Central Vein Occlusion Study Group. A randomised clinical trial of early panretinal photocoagulation for ischaemic central vein occlusion:The early panretinal photocoagulation for ischaemic central vein occlusion:The
central vein occlusion study group N report. Ophthalmology 1995;102: 1434-44.

123 Hayreh SS, Klugman MR, Podhajsky P, Servais GE, Perkins ES. Argon laser panretinal photocoagulation in ischemic central retinal vein occlusion. A 10-year prospective study. Graefes Arch Clin Exp Ophthalmol 1990;228: 281-96.

124 Vannas S, Raitta C. Anticoagulant treatment of retinal vein occlusion. Am f Ophthalmol 1966;62:874-84.

25 Larsson S, Nord B. Some remarks on retinal vein thrombosis and its treatment with anticoagulants. Acta Ophthalmol (Copenh) 1950;28:187-201

126 Kohner EM, Hamilton AM, Bulpitt CJ, Dollery CT. Streptokinase in the treatment of central retinal vein occlusion. A controlled trial. Trans Ophthalmol Soc UK 1974;94:599-603.

127 Vijayasekaran S, Yu DY, McAllister I, Barry C, Constable I. Optimal conditions required for the creation of an iatrogenic chorioretinal venous anastomosis in the dog using argon green laser photocoagulation. Curr Eye Res 1995;14:63-70.

128 McAllister IL, Constable IJ. Laser-induced chorioretinal venous anastomosis for treatment of nonischemic central retinal vein occlusion [see commosis for treatment of nonischemic central r
ments]. Arch Ophthalmol 1995;113:456-62.

129 Vijayasekaran S, Yu DY, McAllister IL, Barry C, Constable IJ. Significance of Bruch's membrane in the creation of iatrogenic chorioretinal venous anastomosis. Curr Eye Res 1994;13:29-33.
130 Hansen LL, Wiek J, Wiederholt M. A randomised prospective study of treatment of non-ischaemic central retinal vein occlusion by isovolaemic treatment of non-ischaemic central retinal vein

131 Glacet-Bernard A, Coscas G, Chabanel A, Zourdani A, Lelong F, Samama MM. A randomised, double masked study on the treatment of retinal vein occlusion with troxerutin. Am F Ophthalmol 1994;118:421-9.

132 Dodson PM, Westwick J, Marks G, Kakkar VV, Galton DJ. $\beta$-Thromboglobulin and platelet factor 4 levels in retinal vein occlusion. $\mathrm{Br}$ f Ophthalmol 1983;67:143-6.

133 Gonder JR, Magargal LE, Walsh PN, Rao K, Denenberg BE. Central retinal vein obstruction associated with mitral valve prolapse. Can f Ophthalmol 1983;18:220-2.

134 Pandolfi M, Isacson S, Astedt B. Coagulation and fibrinolytic studies in 23 patients with occlusion of the retinal vessels. Acta Ophthalmol (Copenh) 1972;50:62-72.

135 McGrath MA, Wechsler F, Hunyor ABL, Penny R. Systemic factors contributory to retinal vein occlusion. Arch Intern Med 1978;138:216-20.

136 Kohner EM, Laatikainen L, Oughton J. The management of central retinal vein occlusion. Ophthalmology 1983;90:484-7.

137 Pulido JS, Ward LM, Fishman GA, Goodwin JA, Froelich CJ, Sanghvi JP. Antiphospholipid antibodies associated with retinal vascular disease [see comments]. Retina 1987; 7:215-8.

138 Kleiner RC, Najarian LV, Schatten S, Jabs DA, Patz A, Kaplan HJ. Vaso-occlusive retinopathy associated with antiphospholipid antibodies (lupus anticoagulant retinopathy). Ophthalmology 1989;96:896-904.

139 Slamovits TL, Klingele TG, Burde RM, Gado MH. Moyamoya disease with central retinal vein occlusion. F Clin Neuro-ophthalmol 1981;1:123-7.

40 Laroche L, Saraux H. Unilateral central retinal vein occlusion in systemic lupus erythematosus. Ophthalmologica 1984;189:128-9.

141 Fountain JA, Werner RB. Tuberculous retinal vasculitis. Retina 1984;4:4850

142 Charteris DG, Khanna V, Dhillon B. Acute posterior multifocal placoid pigment epitheliopathy complicated by central retinal vein occlusion. $\mathrm{Br} \mathcal{F}$ Ophthalmol 1989;73:765-8.

143 Teich SA, Sonnabend J. Central retinal vein occlusion in a patient with AIDs. Arch Ophthalmol 1988;106:1508-9.

144 Friedman SM, Margo CE. Bilateral central retinal vein occlusions in a patient with acquired immunodeficiency syndrome. Clinicopathologic correlation. Arch Ophthalmol 1995;113:1184-8.

145 Sabates R, Hirose T, McMeel JW. Electroretinography in the prognosis and classification of central retinal vein occlusion. Arch Ophthalmol 1983;101: $232-5$. 